\title{
TINJAUAN TERHADAP ASPEK DRAMATIK IKLAN RADIO
}

\author{
Surya Farid Sathotho \\ Institut Seni Indonesia Yogyakarta \\ suryafarid@isi.ac.id
}

\begin{abstract}
Abstrak: Penelitian ini bertujuan untuk melihat adanya aspek dramatis yang membangun sebuah iklan radio dan peran seni teater dalam pembuatannya. Iklan radio sebagaimana drama radio memiliki struktur drama pada umumnya yaitu adanya penokohan, alur, tema, latar, dan dialog. Dari struktur tersebut dapat dilihat adanya aspek dramatik berupa konflik sebagai hakekat drama, suspense dan foreshadowing. Aspek dramatik sebuah iklan sangat penting karena dari situlah sebuah iklan dapat menarik perhatian pendengarnya. Untuk mendapatkannya, konflik dibangun berdasar tema dengan dialog atau monolog. Selanjutnya suspense ataupun foreshadowing seringkali muncul secara bersamaan. Kata atau kalimat yang digunakan untuk ekspresi foreshadowing, seringkali diucapkan dengan pola tertentu yang menghasilkan suspense. Pemahaman teoritis tersebut, disertai latihan praktek yang berhubungan dengan teater ternyata sangat bermanfaat dalam pembuatan iklan radio. Aspek teoritis teater, seperti penulisan dan analisis lakon sangat berguna bagi pembuatan naskah iklan radio. Dari segi praktis, latihan pernafasan, olah vokal, acting auditif sangat membantu mewujudkan iklan radio yang siap diudarakan.
\end{abstract}

Kata kunci: Aspek dramatis, iklan radio, drama radio

\begin{abstract}
Dramatic aspect is very important to build an appropriate radio advertisement and the role of theater art creation. A radio advertisement has a structure such as characterization, plot, theme, setting, and dialog as well, where the dramatic aspect of radio advertisement occurred. It contains conflict as the essence of drama, suspense, and foreshadowing. The dramatic aspect of an advertisement is very important since it where the advertisement able to attract its audience. To achieve such dramatic attraction, conflict is build based on theme with the dialog or monolog. Furthermore, suspense and foreshadowing often appear altogether. Words or sentences to express foreshadowing, often speak out in certain pattern, which create suspense. Theoretical understanding and practical exercises of the theatre happen to be very useful in the making of radio advertisement. The theoretical aspect of the theatre, such as playwriting and text analysis can used in preparing the advertisement's text, while the practical one, such as breathing exercise, vocal, and audio acting is needed in creating the ready on air radio advertisement.
\end{abstract}

Key words: dramatic aspect, radio advertisement, radio drama

\section{Pendahuluan}

Pengetahuan teater baik teori
maupun praktek tidak lagi hanya
diaplikasikan di dalam gedung-gedung
pertunjukan tetapi telah merambah pada hal-

hal yang bersifat praktis. Latihan-latihan dasar teater diaplikasikan pada bidang lain yang membutuhkan penampilan seseorang di depan publik, baik secara auditif, visual, maupun keduanya. Penampilan auditif didukung oleh latihan dasar teater yang 
berkaitan dengan olah vokal maupun pernafasan, penampilan visual didukung oleh latihan dasar teater yang berkaitan dengan olah tubuh. Penyiar radio, televisi, sulih suara, voice over, membutuhkan latihan vokal dan pernafasan. Para peragawati di atas cat walk dibantu dengan latihan olah tubuh. Sedangkan $M C$ harus memahami olah vokal maupun olah tubuh.

Seperti disebutkan sebelumnya, radio merupakan media yang berhubungan dengan aspek auditif seni teater. Meski hanya bersifat auditif, radio sebagai salah satu bentuk teknologi komunikasi mampu bertahan dan berkembang di tengah derasnya perkembangan teknologi komunikasi dan informasi saat ini. Ini terlihat dari perkembangan jumlah stasiun radio siaran yang terus bertambah. Jumlah stasiun radio siaran saat ini jauh lebih banyak dibanding stasiun televisi maupun penerbitan media cetak yang secara tradisi jauh lebih tua. Perhitungan paling sederhana dan mudah adalah dengan melihat jumlah stasiun radio siaran di sebuah kota. Bila dibandingkan dengan jumlah stasiun televisi yang mengudara dan koran yang terbit di kota tersebut, bisa dipastikan jumlah stasiun radio siaran lebih banyak dibanding jumlah gabungan antara stasiun televisi dan surat kabar harian.

Perkembangan jumlah stasiun radio siaran tersebut dipengaruhi oleh beberapa hal. Pertama, karena sifatnya yang auditif memungkinkan untuk dinikmati sambil melakukan aktifitas lain dan tidak terlalu menyita perhatian. Sebagai contoh bisa terlihat dengan adanya radio pada hampir semua mobil. Sangat biasa seseorang mengemudi sambil mendengarkan radio, baik mendengarkan informasi atau sekedar hiburan. Hal ini tentulah tidak mungkin dilakukan dengan media informasi lain yaitu televisi, surat kabar atau bahkan internet sekalipun. Menikmati televisi ataupun surat kabar hanya bisa dilakukan oleh pengemudi kendaraan bermotor disela-sela kemacetan lalu lintas. Ini berarti radio memiliki kemampuan untuk meyesuaikan diri dengan keadaan (Murbandono, 2006).

Kedua, karena secara teknologi memang memungkinkan. Semenjak diperkenalkannya gelombang FM, mutu siaran radio FM semakin baik tidak kalah kualitasnya dengan tape recorder, cd player, atau MP3 player sekalipun sehingga sebagai sarana hiburan dan informasi semakin menyenangkan untuk dinikmati. Meskipun tape recorder, CD player atau MP3 player lebih bisa memberikan hiburan sesuai keinginan kita, tetapi alat ini tidak bisa menggantikan radio dalam memberikan informasi. Padahal saat ini informasi menjadi sesuatu yang sangat berharga. Segala bentuk informasi saat ini bisa di dapat dari radio. Mulai dari kemacetan lalu lintas, kesehatan, gaya hidup, keuangan, dll. Selain itu, jarak pancar gelombang FM relatif pendek sehingga memungkinkan tiap kota memiliki stasiun radio siaran tanpa takut gelombangnya bertabrakan dengan stasiun radio siaran dari kota tetangga (Prayudha, 2005). Hal ini memungkinkan setiap stasiun radio siaran bisa menyusun acara sesuai daerah pancarannya serta disesuaikan dengan kebutuhan setempat. Radio mampu membawa informasi dengan sangat cepat dan up to date. Meski televisi telah mampu melakukannya lebih baik karena dilengkapi gambar, tetapi media ini belum se portable radio. Sampai saat ini, di Indonesia, televisi masih menggunakan gelombang analog sehingga kualitas sinyal yang diterima berubah-ubah bila pesawat televisi berubah tempat. Seperti halnya bila diletakkan dalam mobil yang bergerak (Wijoseno, 2007). Perubahan kualitas sinyal akan mempengaruhi kualitas audiovisual televisi serta tentu berpengaruh pada kenyamanan menikmatinya. Berbeda dengan radio yang bisa didisain sekecil mungkin, hal demikian tidak mungkin dilakukan pada 
televisi maupun koran. Jika terlalu kecil, tentu tidak mungkin melihat gambar atau tulisannya.

Ketiga, menurut perhitungan bisnis, radio masih menjanjikan keuntungan. Kenyataan bahwa stasiun radio siaran selalu bertambah (meski tidak sedikit yang kemudian gulung tikar) menunjukkan bahwa sektor ini masih diminati oleh masyarakat dan juga berarti menjanjikan dalam perhitungan bisnis. Sebagai sebuah industri, perkembangan stasiun radio siaran tidak terlepas dari perhitungan untung rugi dan perhitungan dagang lainnya. Untuk tetap bertahan hidup, stasiun radio siaran harus mendapatkan penghasilan cukup untuk kelangsungan hidupnya.

Seperti media lainnya, stasiun radio siaran mendapatkan penghasilan terbesar dari iklan yang ditayangkan. Iklan yang beredar sekarang ini ada semenjak Jaman Yunani Kuno maupun Romawi Kuno. Awalnya iklan berbentuk pesan berantai dari mulut ke mulut (Noviani, 2002). Sedangkan salah satu iklan tercetak tertua yang pernah ditemukan di Inggris dan berasal dari Jaman Romawi Kuno. Iklan tersebut milik $\mathrm{T}$. Vindaius Arioverstus yang isinya menjajakan "obat paling mujarab dan tidak terkalahkan" dengan merek Chloron, budak belian hijau (Noviani, 2002).

Banyaknya pengeluaran untuk iklan yang dilakukan oleh produsen berbagai barang membuktikan bahwa pihak produsen menganggap media radio masih efektif sebagai sarana pemasaran produk. Karena penyiaran radio memiliki kemampuan untuk meyakinkan pendengar, maka penyiaran radio menjadi alat penting sebagai media periklanan (Prayudha, 2005). Di Amerika, alokasi belanja iklan para produsen di radio mencapai $7 \%$ atau lebih dari 10 trilyun dolar dari seluruh total belanja iklan yang dilakukan produsen pada tahun 1994 (Prayudha, 2005). Angka tersebut hanya kalah dari alokasi belanja iklan di koran sebesar $22,9 \%$ dan televisi $22 \%$, masih lebih besar dari yellow page $6,6 \%$ dan majalah $5,3 \%$ (Prayudha, 2005). Sedangkan di Indonesia, belanja iklan di radio semenjak tahun 1992 mengalami peningkatan signifikan tiap tahunnya kecuali pada masa krisis moneter tahun 1998. Tetapi hal ini segera meningkat kembali pada tahun 2000 . Sebagi ilustrasi, pada jaringan radio Delta FM, tahun 2003 saja mendapat penghasilan Rp. 759.000.000,- dari iklan (Prayudha, 2005).

Iklan di radio seperti juga iklan pada media lain mengalami perkembangan signifikan sejak kemunculan pertamanya. Di Indonesia, perkembangan iklan mulai bergerak pesat setelah tumbangnya Orde Lama (Noviani, 2002). Saat itu iklan mulai diakui sebagai kepanjangan tangan pemasaran barang dan jasa. Hal tersebut seiring dengan munculnya surat kabar, majalah, radio dan bahkan televisi baru (Noviani, 2002). Pada saat itu, iklan masih bersifat informatif, yaitu menekankan pada penjelasan produk yang diiklankan secara detail (Noviani, 2002). Hal ini karena pada saat itu banyak sekali produk baru yang belum dikenal masyarakat, sehingga perlu penjelasan detail tentang produk yang ditawarkan.

Iklan yang ada di radio pada umumnya berupa spot dan sponshorship. Spot yang dijual berukuran standar dengan macam-macam durasi ada yang 10, 20, 30, 40, 60 detik (Prayudha, 2005). Bentuk iklan seperti inilah yang akan menjadi bahan penelitian ini. Sedangkan bentuk lainnya adalah sponsorship. Sponsorship ini biasanya memberikan sponsor terhadap suatu acara di radio sesuai dengan kebijakan manajemen radio yang bersangkutan. Sponshorship biasanya berlangsung relatif lama, mulai dari hitungan minggu sampai tahun.

Siaran radio yang hanya bersifat auditif memberikan ciri tersendiri dalam 
perkembangan iklan yang muncul di radio. Ciri tersebut membedakannya dengan iklan pada televisi yang bersifat audiovisual dan media cetak maupun media luar ruang yang bersifat visual, meski produk yang ditawarkan sama. Sifat auditif iklan radio tersebut sejalan dengan sifat mata acara siaran radio. Hal yang sama juga terjadi dengan sifat audiovisual iklan televisi yang sejalan dengan sifat siaran televisi yang bersifat audiovisual. Ini juga berlaku pada media cetak.

Sifat-sifat tersebut membuat peneliti memiliki asumsi bahwa iklan-iklan di radio memiliki ciri khusus yang hanya dimiliki oleh iklan radio. Ciri tersebut menekankan pada sifat auditif. Sesuai dengan sifat iklan pada umumnya yang bertujuan sebagai motor penggerak ekonomi dalam dunia industri (Noviani, 2002), iklan radio dirancang menurut kaidah dramatik tertentu layaknya sebuah drama audio. Sebagaimana drama panggung, drama audio memiliki struktur tertentu yang terdiri dari tokoh, dialog, alur dan latar (Purwanto, 2006). Oleh karenanya, iklan radio diasumsikan memiliki kaidah-kaidah tersebut. Meski karena keterbatasan durasi tayangnya, kaidah tersebut kadangkala telah mengalami modifikasi sehingga tidak terlihat sejelas pada drama audio.

Untuk membatasi ruang lingkup penelitian, peneliti memfokuskan perhatian terhadap iklan nasional. Yang dimaksud dengan iklan nasional adalah iklan yang memasarkan produk secara nasional. Seperti halnya iklan obat-obatan, makanan, perawatan tubuh dll, yang diproduksi oleh perusahaan-perusahana multinasional. Contohnya Bodrex oleh Grup Tempo, Aqua oleh Danone, Pepsodent oleh Unilever, dll. Meski pada perkembangannya, banyak di antara iklan-iklan tersebut disesuaikan dengan kebutuhan daerah tertentu dengan penggunaan bahasa daerah tempat iklan tersebut ditayangkan. Penelitian akan melihat beberapa iklan radio yang dianggap menarik yang memiliki kaidah-kaidah dramatik tertentu sebagai pembangun struktur iklan tersebut. Dengan demikian, akan terlihat pula unsur-unsur yang membangun aspek dramatik dalam sebuah iklan radio. Hal terakhir yang akan dibicarakan adalah peran seni teater dalam praktek pembuatan iklan radio.

\section{Struktur Iklan Radio}

Iklan radio diasumsikan memiliki struktur sebuah drama radio ataupun drama pada umumnya. Oleh karenanya analisis terhadap aspek dramatik pada sebuah iklan radio akan menggunakan teori strukturalisme yang biasa dipergunakan dalam menganalisis struktur dramatik naskah drama. Teori strukturalisme meneliti karya sastra dalam otonominya, lepas dari latar belakang sosial, sejarah, biografik, dan lain-lain (Teeuw, 1984). Sedangkan Kutha Ratna berpendapat bahwa secara definitif strukturalisme berarti "paham mengenai unsur-unsur, yaitu struktur itu sendiri..." (2004). Unsur-unsur drama, dalam hubungan ini teks drama, di antaranya: tema, dialog, peristiwa atau kejadian, latar atau seting, penokohan atau perwatakan, alur atau plot, dan gaya bahasa (Kutha Ratna, 2004). Adapun Purwanto menyebutkan struktur sebuah naskah drama terdiri dari tokoh, dialog, alur dan latar (2006). Sedangkan menurut Kernodle, dalam naskah drama ada enam unsur yang saling mendukung terjalinnya kesatuan lakuan. Keenam unsur tersebut adalah plot, penokohan, tema, dialog, mood dan spectacle (1967). Tiga unsur pertama dikenal sebagai struktur, sedangkan tiga berikutnya adalah tekstur. Struktur merupakan komponen utama dan merupakan prinsip kesatuan lakuan (unity of action) dalam hubungannya dengan alur (plot) dan penokohan (Oemarjati, 1974). Karya sastra dan drama mengandung gagasan yang 
mungkin dipergunakan untuk menumbuhkan sikap sosial tertentu atau bahkan untuk mencetuskan peristiwa sosial tertentu (Damono, 1978).

Meski memiliki struktur seperti halnya drama panggung, tetapi drama radio memiliki kekhususan tersendiri. Hal tersebut karena drama radio tumbuh berkembang dalam bentuk yang khas dan memiliki hubungan dengan penikmatnya dengan cara yang berbeda (Kernodle, 1967). Dalam drama radio, yang dianggap sama pentingnya dengan dialog, musik dan sound effect adalah announcer yang membawa pendengar pada suasana yang diinginkan (Kernodle, 1967). Pernyataan ini terlihat jelas pada contoh iklan. Announcer memberi penekanan lebih pada klimaks dan konklusi. Penerapan pertimbanganpertimbangan teknis dan artistik pada sebuah iklan radio sangat penting karena pada dasarnya iklan juga merupakan usaha untuk mencetuskan sebuah sikap sosial dan peristiwa sosial tertentu (peniruan, pemilihan produk) melalui penyampaian informasi yang sangat terstruktur, yang menggunakan elemen-elemen verbal dan non verbal (Noviani, 2002).

Tulisan ini akan menggunakan dua buah iklan radio nasional sebagai contoh terhadap analisis struktur dan aspek dramatik.

1. Iklan Kartu AS Telkomsel

Warga A : Pak RT, warga semua sudah pada punya hp. Gimana kalau ada rapat warga kita pakai hp aja, pak?

Warga B : Benar tuh, Pak RT. Kampung kita warganya pada gaul semua

Pak RT : Gaul sih gaul, masalah biaya pulsa siapa yang mau nanggung? Nenek moyang kamu?

Warga A : Ah, pak RT yang nggak gaul. Makanya Pak, kalau mau yang murah dan nguntungin, pakai Kartu As! Nelpon atau sms minimal 30 ribu perbulan dapat kesempatan diundi buat menangin kejutan total satu milyar!

Pak RT : Itu duwit semua?

Warga B : Bukan. Tapi pulsa masingmasing satu juta untuk seribu pemenang, Pak!

Announcer: Promo dari September sampai dengan Desember 2006, dan diundi awal Desember 2006. Untuk pengumuman pemenang 15 Desember 2006. Hadiah ditransfer setiap setiap tanggal 15, setiap bulannya. Mulai 15 Desember sampai dengan September 2007. Ayo, cepetan! Sekarang juga pakai Kartu Asnya.

Bu RT : Eh.. buruan Pak, beliin aku kartu As. Soalnya warga di sini lagi pada telpon-telponan. Biar kebagian pulsa total satu milyar, Pak!

Warga B : He he..Berarti memang Pak RT sama Bu RT kita ini nggak gaul, nih!

Warga A : Iya, nih,payah! Apa kita ganti aja, nih?

Announcer : Kartu As, nomor cumacuma, pakenya suka-suka!

Jingle : (musik) Dari Telkomsel (iklan Kartu As Telkomsel)

\section{Iklan Shampoo Clear Man}

(Dial Telpon). Hallo, Bimo! Ini Nahar... Nahar, Nahar... Eh tadi $l u$ lihat si Radit, nggak? Cari gara-gara tuh, anak. Gua nggak ngerti, apa sih maunya. Selama ini gua bisa sabar ya, tapi itu kan nada batasnya. Gua mesti ngomong, gua mesti ngomong! Ini sudah keterlaluan! $L u$ lihat sendiri, kan. Ini sudah ke tiga kalinya itu anak, pakai baju yang sama ama punya gua. Asli nggak ada bedanya! Warnanya, mereknya, sama persis. Kalau orang lihat di jalan gimana, coba? Muka gua ini mau di taruh di mana? Heeh...

Pantes nggak sih laki-laki kaya gini? Nggak, kan? Sama halnya dengan anda kalau masih pakai samphoo wanita. Pria jelas beda dengan wanita. Begitupun dengan rambut. Rambut pria lebih 
berketombe, lebih mudah rontok dan lebih berminyak.

Clear Technology Center Paris, mempersembahkan Clear Man. Samphoo anti ketombe pertama di Indonesia. Untuk Pria! (Shampoo Clear Man)

Iklan pertama menampakkan adanya struktur drama lengkap. Tema yang disampaikan adalah harga murah Kartu As. Tema ini dinyatakan secara langsung oleh announcer pada bagian akhir iklan dengan kalimat "Kartu As, nomor cuma-cuma, pakenya suka-suka!"

Penokohan terlihat jelas dengan adanya penyebutan nama tokoh yang disebutkan oleh para tokoh lain. Tokoh Pak RT disebutkan pada dialog pembuka dan dialog ke tujuh. Sedangkan tokoh Bu RT disebut pada dialog ke tujuh. Dialog para pelaku juga menampakkan latar cerita adan alur. Latar yang dipakai dalam iklan ini adalah rapat RT. Alur iklan tersebut berupa alur maju dan apabila dilihat menggunakan skema dramatic plot Gustav Freytag terlihat adanya ekposisi, komplikasi, klimak, resolusi maupun konklusi (Harymawan, 1993).

Dialog satu dan dua merupakan eksposisi, tiga sampai lima komplikasi, sedangkan klimaks pada dialog ke enam. Dialog berikutnya merupakan rangkaian resolusi dan konklusi. Adanya beberapa tokoh di dalam iklan tersebut membuatnya seperti sebuah drama radio pendek.

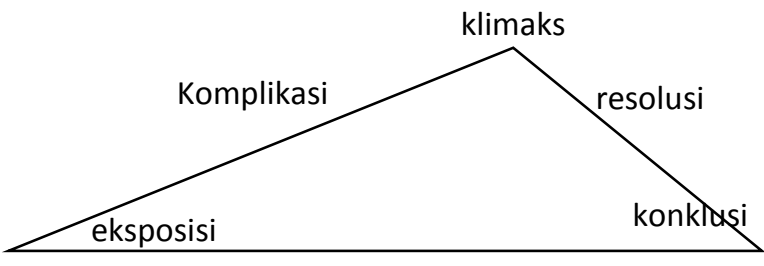

$\underline{\text { Skema dramatic plot Gustaf Freitag }}$

Sedangkan iklan kedua berbentuk monolog. Meski demikian tokoh memperkenalkan diri sebagai Nahar dan menyebut beberapa nama lain sebagai pelaku ceritanya. Seperti halnya iklan pertama, iklan kedua menggunakan kalimat yang diucapkan tokoh untuk menampakkan alur dan temanya. Rasa tidak senang Nahar pada kejadian yang telah terjadi sebelumnya menunjukkan alur flash back digunakan pada iklan ini. Tema Clear Man jelas disampaikan announcer pada bagian akhir sebagai konklusi. Skema dramatic plot Gustav Freitag juga bisa diterapkan pada iklan ini. Pada iklan ini tidak terlihat jelas latar ceritanya.

\section{Aspek Dramatik Iklan Radio}

Unsur-unsur yang membangun aspek dramatis dalam drama adalah konflik, foreshadowing dan suspense. Karena iklan radio diasumsikan sebagai drama radio pendek, maka aspek dramatis iklan radio dianggap sama dengan yang ada pada drama konvensional. Untuk membicarakan aspek dramatis tersebut kembali bisa dilihat pada transkripsi iklan dua buah iklan sebelumnya.

Konflik merupakan hakekat drama. Tanpa adanya konflik, tidak pernah akan ada cerita. Konflik pada iklan pertama didasarkan pada keinginan warga untuk melakukan rapat RT menggunakan HP. Meski terlihat tidak realistis, tetapi hal ini sah-sah saja dilakukan untuk membuat sebuah iklan menjadi menarik. Suspense tercipta saat Pak RT menolak rapat menggunakan HP karena dirasa terlalu mahal. Foreshadhowing pada iklan ini terdapat pada ajakan warga kepada Pak RT untuk melakukan rapat menggunakan HP. Foreshadowing menggiring pendengar pada pernyataan announcer di tengah iklan bahwa menelpon dengan menggunakan Kartu As sangat murah.

Konflik pada iklan kedua terbangun dari ketidak sukaan Nahar terhadap Radit yang memakai baju sama dengannya. Suspense tergambar semenjak awal dari kata-kata Nahar yang disampaikan pada Bimo. Pendengar akan bertanya-tanya apa 
yang terjadi pada keduanya. Pada akhir monolog, terjawab pertanyaan pendengar bahwa Nahar tidak suka karena Radit memakai baju yang sama dengannya. Rangkaian monolog yang diucapkan Nahar ternyata merupakan foreshadowing dari keseluruhan jalan cerita yang ditutup oleh pernyataan announcer bahwa tingkah laku Nahar seperti wanita karena kesukaannya memakai samphoo untuk wanita.

\section{Peran Seni Teater dalam Praktek Pembuatan Iklan Radio}

Aplikasi pengetahuan teater yang bersifat auditif banyak diterapkan pada dunia penyiaran radio. Bagi penyiar radio, suara menjadi satu-satunya penghubung dengan pendengar. Semua bentuk ekspresi diwakili oleh suara, baik senang maupun sedih. Seorang penyiar radio tentulah menggunakan emosi yang berbeda dan menampakkannya secara auditif saat membacakan nama pemenang sayembara atau saat membacakan berita kematian. Perbedaan tersebut harus dikenali oleh pendengarnya. Demikian juga pada drama radio yang biasa di siarkan oleh stasiun radio, harus mampu membawa pendengar pada suasana tertentu. Ekspresi pemeran yang diwujudkan dalam produksi dan olah suara, biasa disebut sebagai akting auditif (Purwanto: 2006, 40). Adapun iklan radio ditampilkan tidak ubahnya sebagai sebuah drama radio dan ditujukan untuk merayu pendengar menjadi konsumen produk yang ditawarkan.

Untuk menguasai akting auditif, seorang pemeran dituntut untuk menguasai segala sesuatu yang berhubungan dengan teknik vokal. Teknik vokal tersebut meliputi teknik pernafasan, artikulasi, intonasi dan penghayatan. Setelah menguasi teknik di atas, pemeran masih dituntut untuk menguasai berbagai suara manusia berdasar jenis kelamin, usia, profesi, karakter. Bila mungkin, ada baiknya dilengkapi pula dengan kemampuan menirukan suara binatang dan benda-benda tertentu dan menirukan dialek dari berbagai suku maupun negara (Purwanto, 2006). Kemampuan dalam bidang ini akan sangat bermanfaat karena memungkinkan pemeran untuk memerankan berbagai macam karakter. Juga memungkinkan double casting atau lebih. Dari sudut pandang produksi, kemampuan ini juga akan menghemat biaya produksi dan mempermudah pengaturan. Asumsinya, mengatur atau menyutradarai sedikit orang lebih mudah dibanding jika harus melakukannya dengan banyak orang.

\section{Simpulan}

Iklan radio sangat menjanjikan karena menawarkan banyak kemungkinan. Hal ini seiring dengan banyaknya radio siaran yang terus berdiri. Radio siaran yang telah ada sebelumnya juga selalu mengembangkan diri. Perkembangan jumlah radio, berbanding lurus dengan banyaknya dana yang dialokasikan para produsen untuk mengiklankan produk mereka melalui media ini. Banyaknya jumlah radio siaran dan produsen barang maupun jasa menyebabkan pangsa yang sangat besar bagi iklan radio. Untuk bersaing mengisi pangsa ini, kita harus memiliki pemahaman yang komprehensif terhadap iklan radio.

Iklan radio tidak ubahnya sebuah drama radio pendek. Memiliki struktur seperti halnya drama konvensional yang dimainkan di atas panggung. Adanya tokoh, dialog, alur dan latar dalam struktur iklan radio menggambarkan hal tersebut. Perbedaan mencolok dengan drama konvensional adalah adanya announcer pada drama maupun iklan radio. Announcer, seperti halnya musik dan sound effect, memiliki fungsi untuk membawa pendengar kedalam suasana tertentu. Oleh karenanya, pengetahuan yang berkaitan dengan drama konvensional, dengan beberapa 
penyesuaian, dapat digunakan untuk memahami dan merancang sebuah iklan radio.

Penokohan pada iklan radio tidak selalu jelas dan memiliki nama. Hal ini berkaitan dengan bentuk iklan radio yang relative pendek. Sehingga gambaran tokoh pada iklan radio seringkali tidak lengkap. Secara fisiologis, seringkali hanya bisa dikenali sebagai laki-laki atau perempuan, anak-anak, remaja, ataupun orang tua. Aspek sosiologis tidak terlihat jelas. Kadang hanya bisa diidentifikasi dengan logat bicara, atau sebutan untuk memanggil, seperti halnya mas, mbak, bang, non, dll. Sementara asapek psikologis tidak Nampak. Tetapi dari pendeknya durasi iklan, tokoh pada iklan dipastikan memiliki karakter datar (flat characterization).

Alur pada kelimabelas iklan yang diteliti menampakkan kesamaan, yaitu alur maju. Nampaknya alur maju ini dipilih disesuaikan dengan kenyataan bahwa durasi yang tersedia untuk iklan sangat sedikit. Dengan alur maju membuat pendengar berfikir linear dan cepat menangkap pesan. Hal ini mengingat dalam siaran radio, seringkali iklan satu diikuti iklan lainnya. Sehingga apabila sebuah iklan memerlukan waktu terlalu untuk dicerna menjadi tidak efektif.

Latar dalam konteks tempat dalam iklan radio tidak selalu nampak jelas. Yang berusaha diciptakan oleh pembuat iklan adalah suasana dengan dialog. Sebagaimana dalam penokohan, latar tempat jarang sekali disebutkan.

Dialog dalam iklan radio pada umumnya bersifat informal, disampaikan semirip mungkin dengan keadaan nyata sehari-hari. Oleh karenanya banyak sekali digunakan kata-kata tan baku dan diucapkan dengan logat khas beberapa daerah di Indonesia. Selain itu digunakan beberapa istilah yang disesuaikan dengan lapisan masyarakat yang dituju oleh pembuat iklan.
Pada beberapa bagian dialog dalam sebuah iklan, sering sekali disisipkan hal-hal lucu untuk membuat pendengar teringat pada iklan dan produk yang ditawarkan.

Tema iklan tidak identik dengan jenis produk yang ditawarkan. Ini terlihat dengan adanya satu macam produk yang ditawarkan dengan berbagai versi iklan dengan latar kejadian yang berbeda. Meski kadang tidak realistis, penuh dengan ungkapan-ungkapan hiperbola dan bombastis, tema demikian dimaksudkan untuk menggugah rasa ingin tahu pendengar.

Kemampuan praktek dalam bidang teater juga sangat bermanfaat dalam pembuatan iklan radio. Akting auditif merupakan bentuk akting yang dibutuhkan di dunia penyiaran radio, termasuk iklan radio. Penguasaan teknik vokal teknik berupa pernafasan, artikulasi, intonasi dan penghayatan sangat menentukan kualitas akting auditif.

Jumlah stasiun radio yang terus bertambah apabila dibarengi dengan kemampuan dalam bidang pembuatan materi iklan dan keahlian praktek akting auditif menawarkan peluang kerja sangat besar bagi praktisi teater.

\section{Daftar Pustaka}

Damono, S. D. (1978). Sosiologi Sastra: Sebuah Pengantar. Jakarta: Pusat Pembinaan Dan Pengembangan Bahasa, Departemen Pendidikan dan Kebudayaan.

Harymawan, RMA. (1993). Dramaturgi, Bandung: Remaja Rosdakarya.

Kernodle, G. R. (1967). Invitation to The Theatre. New York: Harcourt, Brace\&World.

Kutha Ratna, N. (2004). Teori, Metode, dan Teknik Penelitian Sastra. Yogyakarta: Pustaka Pelajar.

Murbandono Hs, L. (2006). Dramaradio Indonesia 1980-an, Tantangan Pendidikan dan Perkembangan 
Manusia. Malang: Pustaka Kayutangan.

Noviani, R. (2002). Jalan Tengah Memahami Iklan. Yogyakarta: LKPPS.

Oemarjati, B. S. (1974). Lakon-lakon Pemenang Sayembara Penulisan Naskah Sandiwara 1974, dalam Pesta Seni 1974. Jakarta: Dewan Kesenian Jakarta.

Prayudha, H. (2005). Radio, Suatu Pengantar untuk Wacana dan Praktik Penyiaran. Malang: Bayumedia.

Purwanto. (2006). Drama Audio, Teks Dramatik, Produksi dan Pemasaran serta Kemediamasaan. Yogyakarta: elKAPHI.

Teeuw, A. (1984). Sastra dan Ilmu Sastra. Jakarta: Pustaka Jaya.

Wijoseno, A. B. (2007, May). TV Mobil, Penghibur di Kala Macet. Intisari vol. 526.

\section{Sumber lain:}

Iklan Kartu As Telkomsel versi Rapat RT

Iklan Shampoo Clear Man versi Samaan 